Оригинални научни рад

УДК 821.163.41.09“04/14“

Примљен: 31. марта 2021.

Прихваћен: 23. маја 2021.

Сара Н. Немат ${ }^{1}$

https://doi.org/10.46630/phm.13.2021.36

Универзитет у Нишу

Филозофски факултет

Департман за србистику

\title{
ОПИС ЧУДА У „ЖИТИЈУ СВЕТОГ СИМЕОНА“ СВЕТОГА САВЕ И СТЕФАНА ПРВОВЕНЧАНОГ
}

У раду се говори о описима чуда која су се, за време његовог земног битисања, пројавила на Светом Симеону, о свечевим постхумним чудотворењима, али и о њиховој паралели са библијским и ранохришћанским чудима. Корпус за ово истраживање представља „Житије Светог Симеона“ Светога Саве и Стефана Првовенчаног. Утврђено је да описи чуда у „Житију Светог Симеона“ одговарају описима Христових јеванђељских чудотворења, као и описима чуда која су чинили ранохришћански светитељи. Циљ рада је да се идентификују поменути описи чуда, као и да се укаже на њихове паралеле. Радом се указује и на особену структуру описа чуда које се сагледава, осим као подразумевани део композиционе схеме житија, и као поджанр у структури хагиографског текста.

Кључне речи: чудо, чудотворење, жанр, „Житије Светог Симеона“, Свети Симеон, Свети Сава, Стефан Првовенчани

\section{1. Појам чуда и чудотворења}

Овим радом биће начињен покушај да се, на примеру „Житија Светог Симеона“ Светога Саве и Стефана Првовенчаног, осветли феномен чуда који је по својој природи интердисциплинаран, с обзиром на то да не фигурира само у књижевности, већ и у теологији и митологији ${ }^{2}$, стварајући на тај начин широк дијапазон значења. Појам чуда потиче из античке књижевности, а у Светом писму добија своју пуноћу, одакле га преузимају и српски средњовековни писци.

Када говоримо о чуду у средњовековној књижевној традицији, најпре треба узети у обзир симбиозу књижевноуметничког и теолошког значења овог појма који се перципира као „необичан догађај који је ре-

1 saranemat3@gmail.com

2 У овом раду нећемо се бавити митолошким аспектом поимања чуда, због тога што би такво истраживање превазишло оквире и постављене циљеве рада. 
зултат деловања Бога“ (BOJOVIĆ 2014: 639).

У теолошком смислу, чудо је пројава Божје милости на богоугодном појединцу, односно „доказ Божјег постојања“ (BULGAKOV 1996: 7). Бог чини чудеса кроз своје светитеље како би објавио своју љубав према вазљьбльенима. Због тога владика Атанасије Јевтић у чуду види врховно заједништво и комуникацију између Бога и човека кроз љубав, која је највеће чудесно и божанско, како у библијској, тако и у нашој средњовековној литератури (VLADIKA ATANASIJE 1993: 117-118). Та безрезервна љубав Божја јављена у свету и човеку у Христу, као ново откровење и нови савез Бога и човека јесте и највеће чудо божанског Откровења (VLADIKA ATANASIJE 1993: 118). У том смислу значајно је и запажање Аверинцева који карактеристичним сматра и само библијско схватање чуда: „То није толико чудо, тј. натприродна ствар колико знак и знамење, тј. нека симболична форма откровења“ (AVERINCEV 1982: 141), због чега се свако чудо суштински сматра микросликом другог доласка Христовог. Стога би најсажетија дефиниција чуда као феномена била да оно представља слику сусрета са Христом, а дефиниција књижевног појма - да чудо представља наративни опис тог сусрета (BOJOVIĆ 2014: 641).

Следствено томе, чуда су дела љубави и милосрђа, а по своме значењу „она су јављања силе човечје у свету, ојачане и просветљене силом Божјом“" (BULGAKOV 1996: 43). Притом, нужан услов чудотворења јесте вера чудотворца која „изазива или прати чудо“ (BULGAKOV 1996: 26), што представља материјализацију речи апостола Павла да „вера спасава љубављу делујући“ (GAL 5, 6). Другим речима, моћ чудотворења сматра се највећим знамењем милости Божје, које од најранијих хришћанских времена представља главну потврду светитељства, а у источнохришћанском свету и његов најважнији предуслов (POPOVIĆ 2006: 59).

Осим као теолошки феномен, чудо можемо сагледати и из перспективе науке о књижевности, где је традиционално сматрано једним од обавезних елемената композиционе схеме житија, а у новије време чудо се перципира и као један од хагиографских (под)жанрова на шта је први пут указано у раду Поетика чуда Драгише Бојовића. У поменутом раду запажено је да чудо показује извесне жанровске одлике, односно да „чудо, истовремено, можемо да перципирамо и као жанровско питање које има двоструки аспект: (1) историјско сагледавање чуда као самосталног жанра и (2) за српску књижевност актуелнији аспект - поимање чуда као поджанра у структури житија“ (BOJOVIĆ 2014: 639).

Треба указати и на особену структуру описа чуда, на основу које се оно сврстава у књижевне жанрове, односно поджанрове. Њу чине три елемента:

1. Молитва мољења Богу, Богородици или одређеном светитељу да 
се чудо деси;

2. Опис чуда (пројава чуда);

3. Молитва (или израз ${ }^{3}$ ) благодарности Богу, Богородици или светитељу за чудо.

Феномен чуда кореспондира са основама фантастичке књижевности, што представља сусрет старог и новог у интерпретацији текстова старе српске књижевности. Одређујући га као апаратуру која повезује видљиво и невидљиво, Предраг Палавестра описе чуда сврстава у жанр фантастике. Житијна чудеса прецизније одређује као она која нису чиста фантастика (фантастика која је сама себи циљ), што имплицира његову поделу на интенционалну и неинтенционалну фантастику. Акцентујући потенцијални утилитаристички карактер хагиографских чуда, он наводи да су „често била у служби профаних, овоземаљских, па чак и практичних државних и ратних потреба“ (PALAVESTRA 1997).

Фантастика је, дакле, присутна у средњовековној књижевности посредством феномена чуда. У том смислу важна је подела фантастичке књижевности коју предлаже Цветан Тодоров. Он најпре прави дистинкцију између чудног и чудесног, одређујући чудно као нешто што се може оправдати законима стварности, а чудесно као домен где закони стварности не делују (TODOROV 1987: 42). С обзиром на ову Тодоровљеву дефиницију, чудо у старој српској књижевности перципира се као чудесно, односно спада у домен где закони стварности не делују. Чудо је, како смо већ рекли, пројава Божје милости на праведнику, а Бог се не може спознати разумом, па самим тим ни његово дело љубави оваплоћено у чуду човек не може рационално објаснити.

На основу до сада реченог, основни циљ рада биће да се укаже на значај описа чуда и на суштину чудотворења житијних јунака у српској средњовековној књижевности на примеру Симеоновог књижевног лика, као и на структуру чуда као поджанра у житијном тексту.

\section{2. Опис чуда у „Житију Светог Симеона“ Светога Саве}

Када је реч о „Житију господина Симеона“, Радмила Маринковић сматра да „о чудима и другим светачким подвизима Немањиним Свети Сава нити је хтео да пише нити је писао“ (MARINKOVIĆ 2007: 99), због чега изостаје већи број описа чуда у свечевом житију. У „Житију Светог Симеона“ описано је само једно право средњовековно светитељско чудо, коме претходи неколико чудесних наговештаја у вези са Немањином смрћу, а то је просветљено лице самртника и његово појање Псалама, као и

3 На пример, као израз благодарности Светоме Ђорђу за избављење из тамнице, Стефан Немања подиже Ђурђеве Ступове. 
откривање свечевог нераспаднутог тела када га, осам година после смрти, Свети Сава откопава ради преноса из Хиландара у Србију (2007: 183).

Први показатељ чудесних елемената у „Житију Светог Симеона“, који антиципира будуће светитељство, јесте просветљење лица умируher ${ }^{4}$ :

„А када је настала ноћ, пошто су се сви опростили и црквена служба, одмах се просветли лице блаженога старца, и, подигавши очи к небу, рече: 'Хвалите Бога међу светима његовим, хвалите га и на тврђи силе његове' (PS 150, 1). А ја му рекох: 'Кога виде те говориш?' А он, погледавши на ме, рече ми: 'Хвалите га и на силама његовим, хвалите га и по премногој владавини његовој' (PS 150, 2). И пошто је ово рекао, одмах испусти свој пребожанствени дух и усну у Господу“ (SVETI SAVA 1986: 114).

Чудесно озарење Симеоновог лица у тренутку предавања свога духа Господу, остаје загонетка како за средњовековног животописца Саву, тако и за читаоца. Може се претпоставити да је Симеон на самрти озарен зато што је видео силу и славу Божју која се не може описати речима, те шапуће стихове Псалама. То је благодат која није дата сваком смртнику, а ни сваком светитељу.

Иако на први поглед Симеонова смрт не подсећа на Исусову, могу се уочити извесне сличности. Неколико тренутака пред Симеонову смрт „просветли се лице блаженог старца“ (1986: 114), а непосредно пред Исусову смрт разагнала се тама по свој земљи (MT 27, 45; MK 15, 33; LK $23,44)$. Пројава светлости у Симеоновим и Исусовим самртним часовима може се протумачити као Божје знамење окупљеним сведоцима. И Христос и Симеон непосредно пред смрт изговарају речи које присутни сведоци не разумеју. Окупљени око распетога Исуса не разумеју кога он у смртном часу дозива (МТ 27, 46-47; MK 15, 34-35), а Свети Сава не разуме због чега монах Симеон на њихова питања одговара стиховима Псалама и пита га: „Кога виде те говориш?“ (1986: 114). Овде је јасно индиковање присуства анђела у тренутку смрти Светог Симеона (MILOJEVIĆ 2018a: 746). Уместо одговора којим би човек привезан за земљу одговорио, монах Симеон одговара анђелским речима које славе Бога: „Хвалите га и на силама његовим, хвалите га и по премногој владавини његовој“ (SVETI SAVA 1986: 114). Обојица се после изговорених речи упокојавају: „И пошто је ово рекао, одмах испусти свој пребожанствени дух и усну у Господу“ (1986: 114), „а Исус опет повика из свега гласа и испусти дух“ (MT 27, 50; MK 15, 37; LK 24, 46). Дакле, Свети Сава је имао узор за описивање Симеонове смрти у Христовим јеванђељима, али је притом користио само поједине мотиве и идеје, а не читаве наводе из Новог завета.

4 УП: MILOJEVIĆ 2017: 9-27. 
Једини типичан опис чуда у „Житију Светог Симеона“ јесте откривање свечевих нетрулежних моштију. „Парадигматична на линији дихотомије: истовремено чудо које превазилази категорије свакодневног, али и очекивана извесност оних који су стремили Богу монашким подвигом, или водећи световни живот успели да у срцу осете љубав живога Бога, јесте непропадивост тела богоугодног појединца“" (MILOJEVIĆ 2018v: 70), о чему Свети Сава у житију овако сведочи:

„И угледавши згодно време да се то изврши, дошавши отворих гроб блаженога старца, и нађох тело његово часно цело и неповређено, које је било ту у гробу осам година. Јер тако приличи онима који су угодили Богу, да су и после своје смрти прослављени, сатвориће Бог вољу оних који га се боје и услишиће њихову молитву, 'сачуваће све њихове кости и ниједна се од њих неће сломити’ (PS 33, 21)“ (1986: 116).

Поменуто постхумно чудо које се пројављује на Светом Симеону представља топос у житијној књижевности, а уједно и знак да Бог увек прославља своје светитеље и да је похвала праведнику од Господа загарантована.

Свети Сава са мало речи, у једноставној приповести и без патетичних узлета мисли, описује чудо велике љубави Божје према своме изабранику, што на први поглед може деловати парадоксално. Разлог томе јесте богољубива мисао-водиља архипастира све српске земље која кореспондира са Псалмопојчевим речима: „Пазићу на путеве своје да не згрешим језиком својим“ (PS 38,1$)$. Он у више наврата у житију напомиње да се боји „да се не умноже речи“ (1986: 99) и „да се не умножи писање“ (1986: 99), јер зна први архиепископ српски да је грех празнословити. Осим тога, Свети Сава не само да је био сведок бројних Божјих чуда, већ је и сам чудотворио благодаћу Светог Духа, те се у складу са тим и опходи према опису чуда у своме делу - као према природној пројави Божје љубави на праведнику, због чега изостаје и фактор изненађења и покушај уверавања читаоца у истинитост описа чудесног знамена.

\section{3. Опис чуда у „Житију Светог Симеона“ Стефана Првовенчаног}

Описи чуда у „Житију Светог Симеона“ Стефана Првовенчаног „прожимају читаво дело - најпре су то чуда на Немањи, пре свега спасавање из заробљеништва уз помоћ Светог Ђорђа, затим победа у бици код Пантина, опет уз помоћ Светог Ђорђа. Потом су ту чуда која чини Немања као светитељ, која су и органски обједињена и чак нумерисана“ (JUHAS GEORGIEVSKA 1988: 38). Сходно томе, уочава се дистинкција на: 1) чуда која су се пројавила на Стефану Немањи и 2) чуда која је постхумно чинио Свети Симеон. 
3.1. Чуда која су се пројавила на Стефану Немањи

У прву групу спадају чудесна Немањина избављења из невоља и Немањине чудотворне борбе против непријатеља. Прво такво место у овом житију припада опису Немањиног избављења из тамнице у коју су га заточила браћа, а у коме се огледа паралела са старозаветним Јосифом (1 MOJS 37, 23-24). Док Јосифа браћа ослобађају тамнице како би га продала у робље (1 MOJS 37, 26-36), Стефан Немања се избавља из заточеништва чудотворном помоћи Светога Ђорђа:

„Док је тако седео у пећини, с тугом у уму свом, са срцем подвижним, мољаше се светом и великом мученику Христову и страстотрпцу, и војнику непобедном, Ђорђу, овако говорећи: „[...] смилосрдовав се, страстотрпче Христов, на мене невоља бедна, похитај Владици својему Исусу Христу, који је обећао испуњавати ти прошења, да ме избавиш сада из муке ове и од уза које ме стежу именом твојим светим, да ти послужим, Свети, за све дане живота мојега, на који начин буде угодно висини страдања твојега, милошћу и милосрђем онога који те је прославио и венчао у свем свету, Христа, на све векове, амин!

Чу страстотрпац Христов молбу овога светог мужа, господина ми, и испуни све што је просио у њега, па овај свети господин мој поче хитно, нимало не задоцнев, зидати храм светога и преславног и великог мученика Христова, Ђорђа, с ревношћу и љубављу, и сврши га...“ (PRVOVENČANI 1988: 68).

У овом опису Немањиног чудесног избављења акцентована је моћ молитве и непоколебљиве вере, о којој су говорили старозаветни пророци, Христови апостоли и многи Свети Оци. Сергеј Булгаков о снази молитве каже да „човек у молитви силом Божјом може да чини чуда. Штавише, свака искрена молитва већ чини чудо, то јест она је деловање духовне узрочности у свету, макар ми и не видели њене спољашње пројаве“ (BULGAKOV 1996: 56). У наведеном примеру из Стефановог дела, спољашња пројава молитве је уочљива и она представља материјализацију Речи Божје да „Отац који види тајно узвраћа јавно“ $($ МТ 6,16$)$ својим праведницима.

У наведеном примеру јасно се уочава структурни модел описа чуда: молитва мољења-чудо-молитва (или израз) благодарности Богу. Стефан Немања, најпре, моли Светога Ђорђа за помоћ, а светац, смиловавши се на праведника и Божјег угодника, силом Духа Светога чудесно ослобађа Немању из тамнице. Након тога следи Немањин израз благодарности у виду изградње манастира у славу и хвалу светом мученику Христовом Ђорђу.

Да Свети Ђорђе никада није оставио Немању без свог заштит- 
ништва сведочи и следећи пример чудесне помоћи у бици код Пантина. Након Немањине молитве Богу и Светом Ђорђу, он

„узев знамење животворнога крста и копље дано му од Владике, иђаше са смелошћу насупрот многим народима. А када је био близу града по имену Звечана, на којем беше сазидана црквица светога и преславног мученика Христова Ђорђа, изабрав једнога од правоверних својих јереја, посла га да твори обноћну молитву, и опет литургију, сву ноћну и дневну службу по реду. А кад је овај заспао од труда, дође свети брзи помоћник, и презвитеру се јави у војничком лику. Јереј га питаше: 'Ко си, господине?' А он рече: 'Ја сам слуга Христов, Ђорђе, који идем на помоћ господину твојему да победим и непријатеље његове.. Сутрадан одмах стекоше се на битку снажну и силну. Божјом помоћу и светога и преславног мученика Христова Ђорђа победи непријатеље своје [...]“ (1988: 69).

Неколико места из наведеног одломка заслужују посебну пажњу. Најпре треба поменути знамење Животворнога Крста које Стефан Немања носи са собом у војни поход. „Његова сила је у томе што је то Крст Христов, средство којим је Христос спасао свет“ (KAPSANIS 2004: 20). Некада се сматрало да сила крста делује од Христове крсне смрти, односно од Новог завета. Међутим, Драгиша Бојовић у своме раду „Старозаветни образ крста“на примерима из конкретних књижевних текстова показује како је крст деловао још у Старом завету:

„Узимајући крст као победни симбол Немањиних битака, Стефан Првовенчани у неколико наврата пореди свог оца са старозаветним личностима којима је, такође, крст помагао у борби против непријатеља. Овога пута реч је о сукобу између Андроника Комнина и Стефана Немање, који 'победи непријатеље своје као Мојсеј Амалика, крст Христов неослабно носећи пред очима и њиме односећи победу над непријатељским варварима' (1988: 200)“(BOJOVIĆ 2006: 200).

Верујући у чудотворну моћ и снагу крста, Немања га носи у битку као правоверно знамење како би њиме спасао своје отачаство од непријатељских напада, у чему је, чудесном силом крста и уз чудотворну помоћ Светога Ђорђа, успео. Дакле, писац житија овде у други план ставља Немањину „руку крепку и мишицу подигнуту“ (PS 135, 12), већ победу над непријатељима приписује благодатној моћи крста. На тај начин истиче се чудотворна моћ „дрвета на коме је Правда обешена“ (PREM 14, 5) и чудесно избављење Немањино помоћу њега.

Следеће место из наведеног описа вредно пажње јесте мотив сна и његов значај:

„Каткада се поимање чуда везује за снове. То су посебни, изузетни сно- 
ви с високим семантичким набојем. Сан се схвата као кодиран текст - порука, чији смисао треба да буде прочитан, а питање тумачења има кључни значај. Посебна пажња посвећује се сновима са појавом светих ликова (Исус Христ, Света Богородица или други светац), где се оцртава неколико основних мотива: захтеви императивног карактера, исцељења, предавање специфичне информације или трансцендентног знања“ (BAEVA 2000: 78).

Имајући у виду поимање и функцију снова Вихре Баеве, уочавамо у наведеном одломку из Стефановог житија, да се у виду светог лика јавља Свети Ђорђе који у сновиђењу предаје специфичну информацију (кодирану поруку) јереју и на тај начин антиципира да ће Господ „свалити у јаму погибли“ (PS 54, 23) Немањине непријатеље. Овај сан има јасну симболику:

„Стефан Немања описан је као борац против зла, што представља пандан борбе Светог Ђорђа против аждаје и истиче његову богопријемљивост, када Божји свеци њему долазе у помоћ. С обзиром на то да сан од Бога долази по усрдној Немањиној молитви, те најављује испуњење траженог, он представља материјализацију речи: 'Иштите и даће вам се, тражите и наћи ћете, куцајте и отвориће вам се. Јер сваки који иште, добија, и који тражи, налази, и који куца, отвориће му се' (LK 11, 9-10)“ (MILOJEVIĆ 2018b: 356).

Пишчева мотивација за увођење мотива сна јесте антиципација будуће Немањине победе на бојном пољу, а његова симболика огледа се у паралели Светог Ђорђа, који припада типу светитеља ратника, и великог жупана Стефана Немање који је искушани војник (ово)земаљских бојева.

\section{2. Постхумна чуда Светог Симеона}

У другу категоризацију спадају чуда која је Свети Симеон творио постхумно. Први такав опис свечевог чудотворства у „Житију Светог Симеона“ Стефана Првовенчаног јесте опис мироточења његових моштију у Студеници уочи годишњице његовог упокојења ${ }^{5}$ :

„И Бог премилостиви, који га је чувао од младости његове, и сад га није оставио, показа човекољубља своја сам господином светим на нама, слугама његовим. И источи рака његова миро чудна и пријатна мириса, исцељујући болне и страдања различна и, просто рећи, прогонећи бесне духове. И не само једном, него и у све часове истицаше

5 Назнаку о томе да су Симеонове мошти мироточиле најпре на Светој Гори, где се и упокојио, имамо у речима Стефана Првовенчаног који упућује молбу брату Сави да у земљу отачаства Симеоновог пренесе „пријатна мириса мошти Светога“ (87 :1988). Дакле, у наведеном примеру писац алудира на чудо које се десило у Хиландару, али у делу изостаје сам опис тог чуда. 
неисказано и преславно миро отачаству својему“ (1988: 88-89).

Дакле, „мироточење је било основни вид Симеоновог посмртног јављања и главни агенс чудотворења“ (POPOVIĆ 2006: 62), што значи да ово чудо са разлогом заузима водеће место у каталогу свечевих посмртних чудотворења. Поменутом опису чуда последују чудесна исцељења бесомучних и других потребитих страдалника која су се догодила на Симеоновом гробуб. Паралела овом опису јесу јеванђељске параболе о Христовим чудотворним исцељењима:

„И приведоше му све болеснике, разним болестима и мукама обузете, и бјесомучне, и мјесечаре, и одузете, и исцијели их“ (МТ 4, 24; 14, 14; 15, 30; MK 1, 32-34; LK 4, 40; 6, 18; 7, 21; 9, 11).

Следеће Симеоново чудо описано у житију јесте чудесно исцељење бесомучног на Симеоновом гробуㄹ:

„Кад су игуман Дионисије и сви чрнци који су ту служили службу и бдење ноћно у храму Пресвете Богородице, ту где леже мошти Светога допаде неко обузет бесом који га мучаше по све дане, који се никако не умириваше, него га свагда бес гоњаше ван васељене, кроз горе и камење“ (1988: 89).

Након искрене и усрдне молитве на гробу Светога, бесомучни добија исцељење:

„Помилуј, Свети, мене који није очекивао спасења, и избави, Пречасни, онога који је сасвим пропао и порабоћен бесу лукавоме, који влада њиме, јер смо ми стадо отачаства твојега. Не дај нас бесовима на радост, него нас избави пречистим молитвама својим, имајући потом слободе ка Владици [...] и одмах, умилосрдивши се, исцели га. И отиде дому својему радујући се и славећи Бога, који је дао силу угодницима својим“ (1988: 89).

Сада је, за разлику од претходно описаних чуда где је Симеон прималац чудесне помоћи од светог Божјег угодника, он чудесни посредник у молитвама бесомучног по угледу на свога учитеља Христа:

„А када би вече, доведоше к њему бјесомучних много, и изагна духове ријечју“ (МТ 8, 16; 8, 28-34; MK 5, 2-13; LK 8, 27-36).

Симеон, за разлику од Христа, не исцељује речју, јер ово чудо твори постхумно. Оно што је карактеристично за овај опис чуда јесте да

6 „Поред подражавања излечења бесних из јеванђеља, у житијима [...] додају се излечења моштима светаца“" (AJDAČIĆ 2000: 357).

7 УП. MILOJEVIĆ $2018 \mathrm{~g}$ 
бесомучник прима исцељење у близини предмета који је био у додиру са Светим Симеоном, а то је камен са свечевог гроба, односно мермерни саркофаг под којим је почивало свечево тело.

Приликом описа исцелитељских чуда „често и стање онога који чека исцељење делује потресно“ (BOJOVIĆ 2014: 647). Такав је случај са богаљем који прима чудесно исцељење на Симеоновом гробу:

„Човек неки богаљ пужаше на ногама својим, и не могаше се никако усправити, нити могаше стати на ноге своје, јер му обе ноге бејаху одузете и прегореле огњем у коленима, замало што нису сасвим отпале и не држаху се. Како су жиле биле изгореле, плазећи на рукама својим, вукао је за собом ноге своје. И, нашав га пречасни Сава, отац мој, завив га у врећу, принесе га моштима Пречаснога, просећи у њега исцељења му. Јер немоћни чув о чудесима која бивају и исцељењима од Светога, кричаше и вапијаше, говорећи: 'Помилуј, Свети, мене који је пропузио гресима својим и који је убијен од злих разбојника и лежи још жив. Јер као што је Владика твој исцелио пређе ослабљенога да је овај одар узео и да ходи право, тако као и ти, Свети, ако хоћеш можеш ми помоћи милошћу даном ти од Бога и Спаса твојега Исуса Христа. Исцели ме, грешнога, као ученик прави Христа твојега“ (1988: 89-90).

Овај опис чуда представља пишчеву алузију на Христово исцелитељско чудо описано код свих његових јеванђелиста:

„И гле, донесоше му одузетога који лежаше на одру. И видјевши Исус вјеру њихову, рече одузетоме: Не бој се чедо, опраштају ти се гријеси твоји [...] Тада рече одузетоме: Устани, узми одар свој и иди дому своме. И уставши отиде дому своме“ (МТ 9, 2-7; MK 2, 3-5; 2, 11-12; LK 5, $18-20 ; 5,24-25$; JN 5, 2-9).

Симеоново исцелитељско чудо које кореспондира са Христовим представља материјализацију Исусових речи да ће свако ко верује и следи га моћи да чини дела која је и он чинио $(\mathrm{JN} \mathrm{14,12):}$

„А он, Свети, који свагда милује стадо своје, исцели овога ослабљеног и учини га да право ходи. И скакаше читав ногама својим захваљујући Светој Тројици: Оцу и Сину и Светоме Духу, и пречасноме и светом Симеону, који му је дао да ходи ногама својим'“ (1988: 90), а могло би се додати и захваљујући Светоме Сави, који се са одузетим заједно молио за чудо исцељења, да се испуни реч Божја: „Гдје су два или три сабрана у име моје, ондје сам и ја међу њима“ (МТ 18, 20).

Писац не заборавља да спомене да се чудо догодило најпре захваљујући Богу, јер је Он једини лекар наших душа и тела, и да кроз апостоле и светитеље Он лечи, односно да они могу лечити само у његово име и сматрају се тек посредницима у чудесном исцељењу. Оваква објашњења 
су потребна, јер су људи у случају чудотворног оздрављења више склони да величају чудотворца него Бога (LARŠE 2008: 74).

За разлику од Христа који у свом отачаству није чинио чуда због неверја тамошњег народа ${ }^{8}$, из наведених примера јасно је да се на гробу Симеоновом у Студеници, дакле, у земљи његовог отачаства, дешавају чудесна исцељења. То говори о снази вере коју су свештена двојица, Свети Симеон и Свети Сава, утврдила у српској земљи. О томе сведочи и Стефан Првовенчани у похвали Светом Симеону:

„Ниједан пророк није примљен у отачаству својем (LK 4, 24), а ти се у отачаству својем јави велики заступник, пуштајући да кипи пребогато миро из раке твоје, исцељујући свако свезивање сотонино, и прогонећи бесна маштања, и лијући недужнима реке исцељења, који притичу к теби“ (1988: 96), стварајући на тај начин антиподну слику између Симеона и осталих светитеља (пророка) дајући предност Симеону, што представља хагиографски топос приликом обликовања похвале одређеном свецу.

Претходна три описа Симеонових чуда догађају се у Студеници, на његовом гробу. Тамо ће потећи миро, биће излечење бесом обузетога и један раслабљени ће се подићи. То су типична светитељска чудеса (BOJOVIĆ 2009: 94).

Следећа четири описа чуда у житију односе се на Симеонову чудотворну помоћ Стефану Првовенчаном у биткама ради одбране државних и династичких интереса вођених против: 1. бугарског цара Борила и грчког цара Филандра; 2. бугарског одметника Стреза; 3. драчког цара Михаила и 4. угарског краља Андрије са којим се удружује грчки цар Филандар. Епилог прва три непријатељска напада јесте приказивање последица њихове намере, а то је чудотворно окретање зла против непријатеља самог. Поменути тип чуда који се дешава услед интервенције Светог Симеона Снежана Милојевић назива „чудом које зауставља зло“ (MILOJEVIĆ 2019: 283) које је усмерено ка богоугодном праведнику, а Даница Поповић „негативним чудом“ (POPOVIĆ 2006: 61), јер за исход има казну, односно смрт непријатеља. Последње, накнадно придодато, чудо описано у житију има другачију функцију и представља повест о помирењу завађених непријатељских страна, од којих су на једној Андрија и Филандар, а на другој Стефан Првовенчани. Оно је истовремено и имплицитна порука о љубави, која је и главни агенс за пројаву чуда.

Дакле, Симеоново чудотворно заштитништво започиње свечевим јављањем приликом похода бугарског цара Борила и грчког цара Филандра, који су договорили састати се у „славном Константиновом

8 Да се испуне речи Божје: „По вјери вашој нека вам буде“ (МТ 9, 29). 
граду“ (1988: 90) Нишу, одакле је требало да изврше напад на Стефана Првовенчаног. Након прозрења њихове намере и усрдне молитве, Свети Симеон чудесно расејава његове непријатеље тако што зарате једни против других:

„И расу невидљиво пречасни непријатеље наше који се беху дигли. И страхом великим обузети, појавом мојега господина светог и знамењем једним, побеђени од њега побегоше, секући сами себе, једни друге, и победа им би међу собом, и до краја се срушише“ (1988: 91).

Поменуто житијно место значајно је по томе што „на овом примеру, видимо да се Свети пројављује у Нишу, на месту овоземаљских победа својих. Поред тога што остварује улогу заштитника отачаства, он се на овом примеру појављује и као заштитник града и области које је некада мачем освојио“ (2009: 95), због чега се може направити паралела између Светог Симеона и Светог Димитрија Солунског, не само по типу светитељства (свети ратник), већ и по заштитништву специфичне области (града).

У овом примеру фигурира и мотив крста, јер непријатељи нису побеђени само појавом Светог Симеона, већ и „знамењем једним“ (1988: 91), чиме се алудира на крсно знамење, које представља непобедно оружје у борби против непријатеља, односно истиче се као симбол победе у хришћанским биткама.

Следећа два чуда у житију такође описују изненадну смрт Стефанових непријатеља, која се може перципирати као казна за учињена недела „која светитељ чини тако што кажњава или усмрћује непријатеље својих штићеника“" (POPOVIĆ 2006: 61).

Један од таквих описа чуда јесте Симеонова помоћ услед Стрезовог напада на Првовенчаног која за епилог има изненадну непријатељеву смрт:

„Одмах помоћу пресвете Богородице и силом Светога Симеона, који подржава крепким дланом отачаство своје, би ово. Као што добропобедни и помоћљиви и отачаствољубац, Димитрије страстотрпац прободе цара, рођака свога, и умори злом смрћу, не дајући вређати отачаства својега, тако и овај мој свети господин, помажући и чувајући отачаство своје, прободе овога злотвора. И издахну усред народа злом смрћу, и смрћу чудном, да су се сви чудили томе“ (1988: 93).

Док се из претходног примера имплицитно ишчитава паралела са Светим Димитријем, у овом примеру она је експлицитно наведена. Даница Поповић у овом пишчевом поступку види важну богословску чињеницу о међусобној заменљивости светачких својстава, функција и чуда која се базирају на еклисиологији Светог апостола Павла, односно 
на заједништву (саборности) светитеља у Исусу Христосу и Цркви Христовој. Схватање о преносивости трансцендентне суштине подразумева и уверење о чврстој вези светих, а оно теолошки оправдава могућност да се дела и чуда једног светитеља преузимају из житија другог (POPOVIĆ 2006: 60).

И следећи опис Симеонове чудотворне помоћи приликом напада драчког цара Михаила има исти исход као и у претходно описаном чуду. Након Стефанове молитве оцу, Свети Симеон чудесно развејава непријатеље свога отачаства:

„овај пречасни Свети Симеон, топал у молитвама, и брз да походи [...] умоли својом молитвом светога и великог мученика Христова Ђорђа, кога узе себи за помоћника и победиоца над непријатељима, и као што Меркурије прободе нечастива мучиоца Јулиана, тако и овај великомученик такну у ребра игумана својега Јанићија, у храму свом у средини српске земље, говорећи: 'Устани, проповедај величину моју! Јер сам ја послан од Господа да убијем Михаила Грка, који је у драчкој страни'. И одмах један од робова његових, устав, прободе га мачем на одру његову, и злом смрћу предаде душу своју, на срамоту гледаоцима, а на радост свима који се уздају у Господа и у свете угоднике његове“ (1988: 94-95).

У наведеном примеру интензивира се чудотворно деловање Светог Симеона јер за помоћника узима Светога Ђорђа. Потреба за двоструком помоћи у бици Стефану Првовенчаном имплицира борбу против снажнијег непријатеља, где се, опет, јавља (наизглед) парадоксална ситуација да слабији побеђује јачег. Међутим, Стефан побеђује непобедном силом хришћанске вере, али и заступништвом националног светитеља - Светог Симеона. У поменутом примеру писац прави паралелу и са ранохришћанским светитељем - Меркуријем, што је сведочанство о Стефановом познавању житија ранохришћанских светитеља, односно о богатој књижевној традицији коју је писац имао за литературу.

Претходна три описа чуда немају поткрепљење у библијским изворима, али имају паралелу у житијима светих ратника Димитрија Сoлунског, Светог Георгија и Светог Меркурија, који су се мачем борили против непријатеља, као што је и Немања за живота чинио. Специфично је да сви поменути светитељи припадају типу светих ратника, којима се придружује и Свети Симеон, с обзиром на то да је, као владар и војсковођа, значајан део свог живота провео на бојном пољу.

Последње у низу чуда Светог Симеона у делу Стефана Првовенчаног јесте чудотворна свечева помоћ приликом напада угарског краља Андрије и грчког цара Филандра (1988: 98). Стефан, стога, прибегава молитви за помоћ пред гробом свога оца услед које долази до поновног, ин- 
тензивнијег, истицања мира:

„приспе Дух Свети, и испуни се пријатномирисне масти сва црква и изли се мирисно миро, не као што се излива у све дане, него се поли сва црква, да изнемогоше служиоци код светога гроба црпући свето миро“ (1988: 98).

За целовито сагледавање Симеоновог чудотворног лика важно је и да су, осим гроба, мироточиве биле и његове фреске:

„И из исписанога лика Светога, који је на зиду црквеном, истече пречудна река, да су се сви гледаоци дивили“ (1988: 98).

Комплементарна чудотворна својства Симеонових моштију и иконе имплицирају начелну истоветност њихове суштине и функције. Поштовање икона и реликвија почива на различитим теолошким постулатима и везује се, као доминантан облик побожности, за две различите традиције - култ икона за источнохришћански, а реликвија за западни свет - заједнички им је био начин деловања (POPOVIĆ 2006: 64).

Након усрдне молитве за чудесно избављење, Стефан одлази Сави по благослов и полази у битку против непријатеља.

„Благодат Симеонова и молитва Савина учиниће да Стефан Првовенчани и краљ Андрија склопе мир, након дванаест дана преговора у граду Равно (данашња Ћуприја). Двојица владара ће после тога кренути према Нишу, да би се састали са царем Хенрихом. Првовенчани не пропушта прилику да још једном истакне да су се састали у славном граду Нишу, одакле су Хенрих и Андрија отишли посрамљени. Ниш је напустио и Стефан Првовенчани са свешћу да се у овом граду још једном пројавила слава Господња и на делу показала брига Светог Симеона за отачаство своје и град Ниш“ (2009: 96).

Оно што је специфично, јесте да се пројава првог и седмог (последњег) чуда која се тичу чудотворне Симеонове помоћи Стефану Првовенчаном у борбама против непријатеља везују за одређени локалитет - славни Константинов (а могло би се рећи и Немањин) град Ниш, творећи кружну хагиографску структуру, која симболички затварају круг Немањиних чудотворних јављања у земљи свога отачаства. Имајући у виду чудотворно јављање Симеоново у Нишу и перцепцију чуда као пројаву Божје љубави, може се рећи да је Ниш град Божје благодати, љубави и вере, а истовремено и наде да ће се рука Божја у векове пружати над њим.

На крају, Стефан Првовенчани упућује на веродостојност свога дела, чија су залога речи: „Милосрђем Господа Бога и Спаса нашега Исуса Христоса и милошћу Пречисте Богородице и увек деве Марије, сва су ова чуда, славна и преславна, од светога господина мојега Симеона била 
на мени бедном и недостојном и грешном, рођеном и васпитаном њиме, бедном Стефану“ (1988: 95), што упућује на то да поменуте описе чуда треба перципирати као праву историографију, а не само као књижевноуметничку фикцију.

\section{4. Закључак}

Свети Симеон, попут бројних националних светитеља, није чудотворио за време свог земаљског битисања, али је још за живота био Божји изабраник на коме су се пројавила многа чудеса. У Савином „Житију Светог Симеона“, описано је само једно, и то постхумно чудо које се пројавило на светитељу - нетрулежност његовог тела, које је један од индикатора светитељства. У „Житију Светог Симеона“ Стефана Првовенчаног, описана су два чуда која су се пројавила на Стефану Немањи за живота и оба уз помоћ Светог Ђорђа и још седам чуда која је он, као светитељ, чинио.

Прва три чуда су мироточење, исцељење бесомучног и подизање раслабљеног, а оно што је специфично у вези са њима јесте да се сва три дешавају у Студеници. Чуда исцељења бесомучног и подизања раслабљеног описана су по узору на Христова исцелитељска чуда, са том разликом што се чуда у „Житију Светог Симеона“ дешавају после свечеве смрти на његовом гробу и у контакту потребитог са предметом који је био у додиру са светитељем.

Потоња четири описа чуда односе се на Симеонову чудотворну помоћ Стефану Првовенчаном у биткама. На тај начин задовољена су оба аспекта Симеоновог лика - светитељски и владарски, а суштина је благодатна и чудотворна свечева помоћ чедима свога западног отачаства, по чему се пореди са Светим Ђорђем, Светим Димитријем и Светим Меркуријем.

У описима свих поменутих чуда из „Житија Светог Симеона“ Стефана Првовенчаног уочава се утврђена структура: молитва мољења-опис чуда (чудотворство)-молитва благодарности, што иде у прилог мишљењу да се чудо може перципирати као самостални жанр, односно поджанр српске средњовековне књижевности, с обзиром на то да има аутономну структуру и да се може посматрати и изоловано од хагиографског текста коме структурно припада.

\section{Цитирана литература}

AJDAČIĆ 2000: Ajdačić, Dejan. „Čudesno isceljenje opsednutih“. Čudo u slovenskim kulturama, Beograd: Naučno društvo za slovenske umetnosti i kulture, Novi Sad: APIS, 2000. [orig.] Ајдачић, Дејан. „Чудесно исцељење опседнутих“. 
Чудо у словенским културама, Београд: Научно друштво за словенске уметности и културе, Нови Сад: АПИС, 2000.

AVERINCEV 1982: Averincev, Sergej. Poetika ranovizantijske književnosti. Beograd: Srpska književna zadruga, 1982. [orig.] Аверинцев, Сергеј. Поетика рановизантијске книжевности. Београд: Српска књижевна задруга, 1982.

BAEVA 2000: Baeva, Vihra. „Čudo kao lični mit“. Čudo u slovenskim kulturama, Beograd: Naučno društvo za slovenske umetnosti i kulture, Novi Sad: APIS, 2000. [orig.] Баева, Вихра. „Чудо као лични мит“. Чудо у словенским културама, Београд: Научно друштво за словенске уметности и културе, Нови Сад: АПИС, 2000.

BOJOVIĆ 2014: Bojović, Dragiša. „Poetika čuda“. Zbornik Matice Srpske za književnost i jezik, knj. 62, sv. 3, Novi Sad, 2014. [orig.] Бојовић, Драгиша. „Поетика чуда“. Зборник Матице Српске за книжевност и језик, књ. 62, св. 3, Нови Сад, 2014.

BOJOVIĆ 2009: Bojović, Dragiša. „Niš u književnom delu Stefana Prvovenčanog“. Razvijanje svitka, prilozi iz istorije. Niš: Centar za crkvene studije, Beograd: Ars Libri, 2009, 87-100. str. [orig.] Бојовић, Драгиша. „Ниш у књижевном делу Стефана Првовенчаног“. Развијағе свитка, прилози из историје. Ниш: Центар за црквене студије, Београд: Ars Libri, 2009, 87-100. стр.

BOJOVIĆ 2006: Bojović, Dragiša. „Starozavetni obraz krsta“. Crkvene studije, godišnjak Centra za crkvene studije, 3, Niš, 2006, 199-212. str. [orig.] Бојовић, Драгиша. „Старозаветни образ крста“. Црквене студије, годишғак Центра за ирквене студије, 3, Ниш, 2006, 199-212. стр.

BULGAKOV 1996: Bulgakov, Sergej. O evanđelskim čudima. Beograd: Logos, 1996. [orig.] Булгаков, Сергеј. О еванђелским чудима. Београд: Логос, 1996.

JUHAS GEORGIEVSKA 1988: Juhas Georgievska, Ljiljana. „Stefan Prvovenčani i njegovo delo“. Žitije Svetog Simeona. Beograd: Prosveta, Srpska književna zadruga, 1988, 9-50. str. [orig.] Јухас Георгиевска, Љиљана. „Стефан Првовенчани и његово дело“. Житије Светог Симеона. Београд: Просвета, Српска књижевна задруга, 1988, 9-50. стр.

KAPSANIS 2004: Kapsanis, Georgije. Krst Hristov i njegov značaj u našem životu. Beograd, 2004. [orig.] Капсанис, Георгије. Крст Христов и юегов значај у нашем животу. Београд, 2004.

LARŠE 2008: Larše, Žan Klod. Teologija bolesti. Prev. Radmila Obradović, Niš: Centar za crkvene studije, Beograd: Ars Libri, 2008. [orig.] Ларше, Жан Клод. Теологија болести. Прев. Радмила Обрадовић, Ниш: Центар за црквене студије, Београд: Ars Libri, 2008.

MARINKOVIĆ 2007: Marinković, Radmila. Svetorodna gospoda srpska. Beograd: Čigoja, 2007. [orig.] Маринковић, Радмила. Светородна господа српска. Београд: Чигоја, 2007.

MILOJEVIĆ 2019: Milojević, Snežana. „Čudo koje zaustavlja zlo na primerima iz stare srpske književnosti“. Vizantijsko-slovenska čtenija II. Ur. Dragiša Bojović, Niš: Centar za vizantijsko-slovenske studije, Međunarodni centar za pravoslavne studije, Centar za crkvene studije, 2019, 283-293. [orig.] 
Милојевић, Снежана. „Уудо које зауставља зло на примерима из старе српске књижевности“. Византијско-словенска чтенија II. Ур. Драгиша Бојовић, Ниш: Центар за византијско-словенске студије, Међународни центар за православне студије, Центар за црквене студије, 2019, $283-$ 293.

MILOJEVIĆ 2018a: Milojević, Snežana. „Funkcija anđela u opisu stradanja i smrti srpske žitijne književnosti XII i XIII veka“. Crkvene studije god. 15 br. 15, Ur. Dragiša Bojović, Niš: Centar za crkvene studije, 2018. [orig.] Милојевић, Снежана. „Функција анђела у опису страдања и смрти српске житијне књижевности XII и XIII века“. Црквене студије год. 15 бр. 15, Ур. Драгиша Бојовић, Ниш: Центар за црквене студије, 2018.

MILOJEVIĆ 2018b: Milojević, Snežana. „Funkcija snova i viđenja u staroj srpskoj književnosti na primerima opisa stradanja i smrti“. Vizantijsko-slovenska čtenija I. Ur. Dragiša Bojović, Niš: Centar za vizantijsko-slovenske studije, Međunarodni centar za pravoslavne studije, Centar za crkvene studije, 2018, 347-369. [orig.] Милојевић, Снежана. „Функција снова и вићења у старој српској књижевности на примерима описа страдања и смрти“. Византијско-словенска чтенија I. Ур. Драгиша Бојовић, Ниш: Центар за византијско-словенске студије, Међународни центар за православне студије, Центар за црквене студије, 2018, 347-369.

MILOJEVIĆ 2018v: Milojević, Snežana. „Čudo nepropadivosti tela i mirotočenja svetih u srpskoj žitijnoj književnosti“. Philologia Mediana br. 10, Niš, 2018. [orig.] Милојевић, Снежана. „Чудо непропадивости тела и мироточења светих у српској житијној књижевности“. Philologia Mediana бр. 10, Ниш, 2018.

MILOJEVIĆ 2018g: Milojević, Snežana. „Čudo isceljenja u žitijima srpske srednjovekovne književnosti“. Oktoih VIII/9, Podgorica, 2018, 109-122. [orig.] Милојевић, Снежана. „Чудо исцељења у житијима српске средњовековне књижевности“. Октоих VIII/9, Подгорица, 2018, 109122.

MILOJEVIĆ 2017: Milojević, Snežana. Od premudrih čula. Ogledi o staroj srpskoj književnosti. Niš: Međunarodni centar za pravoslavne studije, 2017. [orig.] Милојевић, Снежана. Од премудрих чула. Огледи о старој српској књижевности. Ниш: Међународни центар за православне студије 2017.

PALAVESTRA 2007: Palavestra, Predrag. Kritičke odlike srpske fantastike. Projekat Rastko, nepaginirano. <http://www.rastko.rs/rastko/delo/11841> 11. 4. 2021. [orig.] Палавестра, Предраг. Критичке одлике српске фантастике. Пројекат Растко. Непагинирано. <http://www.rastko.rs/ rastko/delo/11841> 11.4. 2021.

POPOVIĆ 2006: Popović, Danica. „O nastanku kulta Svetog Simeona“. Pod okriljem svetosti. Kult svetih vladara i relikvija u srednjovekovnoj Srbiji, Beograd: Balkanološki institut SANU, 2006. [orig.] Поповић, Даница. „О настанку култа Светог Симеона“. Под окриљем светости. Култ светих владара и реликвија у средњовековној Србији, Београд: Балканолошки институт 
CAHУ, 2006.

TODOROV 1987: Todorov, Cvetan. Uvod u fantastičku književnost. Beograd: Rad, 1987.[orig.] Тодоров, Цветан. Увод у фантастичну книжевност, Београд: Рад, 1987.

VLADIKA ATANASIJE 1993: Vladika Atanasije, Jevtić. „Božansko i čudesno u srpskoj religioznoj književnosti. Srpski zavičaj, Priština: Jedinstvo, 1993. [orig.] Владика Атанасије, Јевтић. „Божанско и чудесно у српској религиозној књижевности“. Српски завичај, Приштина: Јединство, 1993.

\section{Извори}

BIBLIJA: Sveto pismo Staroga i Novoga zavjeta. Prev. Đuro Daničić i Vuk Stefanović Karadžić. Beograd: Glas mira, Preporod, 2009. [orig.] Библија: Свето писмо Старога и Новога завјета. Прев. Ђуро Даничић и Вук Стефановић Караџић. Београд: Глас мира, Препород, 2008.

SVETI SAVA 1986: Sveti Sava. Žitije Svetog Simeona. Beograd: Prosveta, Srpska književna zadruga, 1986. [orig.] Свети Сава. Житије Светог Симеона. Београд: Просвета, Српска књижевна задруга, 1986.

STEFAN PRVOVENČANI 1988: Stefan Prvovenčani. Žitije Svetog Simeona. Beograd: Prosveta, Srpska književna zadruga, 1988. [orig.] Стефан Првовенчани. Житије Светог Симеона. Београд: Просвета, Српска књижевна задруга, 1988.

Sara N. Nemat

MIRACLES IN THE “LIVE OF SAINT SIMEON” BY SAINT SAVA AND STEPHEN THE FIRST-CROWN

The paper talks about the descriptions of miracles that appeared on Saint Simeon during his earthly existence, about the saint's posthumous miracles, but also about their parallel with biblical miracles. The corpus for this research is represented by the "Live of Saint Simeon" by Saint Sava and Stephen the First-crowned. It has been established that the descriptions of miracles in the "Life of Saint Simeon" correspond to the descriptions of Christ's gospel miracles, as well as to the descriptions of miracles performed by early Christian saints. The aim of this paper is to identify the mentioned descriptions of miracles, as well as to point out their parallels. The paper also points out the special structure of the description of miracles that is considered, except as an implied part of the compositional scheme of hagiography, and as a subgenre in the structure of the hagiographic text.

Keywords: miracle, miracle-working, genre, "Life of Saint Simeon", Saint Simeon, Saint Sava, Stefan the First-crowned 